Gelanggang Olahraga: Jurnal Pendidikan Jasmani dan Olahraga

Volume 2, Nomor 1, Juli-Desember 2018

e-ISSN : 2597-6567

p-ISSN : 2614-607X

DOI : https://doi.org/10.31539/jpjo.v2i1.420

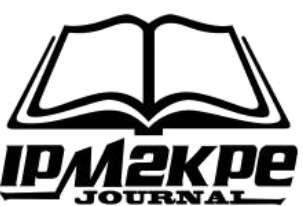

\title{
TINJAUAN KONDISI FISIK WASIT SEPAK BOLA PENGCAB PSSI KOTA LUBUKLINGGAU
}

\author{
Azizil Fikri \\ STKIP-PGRI Lubuklinggau \\ azil_azizil@yahoo.com
}

\begin{abstract}
ABSTRAK
Tujuan penelitian untuk meninjau kondisi fisik wasit sepak bola Pengcab PSSI Kota Lubuklinggau. Populasi dalam penelitian ini adalah wasit sepakbola yang berdomisili di kota Lubuklinggau dan terdaftar pada pengcab PSSI Kota Lubuklinggau yang berjumlah 15 orang. Teknik pengambilan sample adalah total sampling. Karena jumlah populasi yang relatif sedikit, maka semua populasi dijadikan sampel yaitu sebanyak 15 orang. Berdasarkan hasil pengolahan data dengan menggunakan SPSS Versi 12.00 terdapat bahwa sig. $0.918>0.05$, maka data Daya tahan Wasit dapat dikatakan berdistribusi normal. Kecepatan Wasit berada pada kategori baik dengan rata-rata 4 dan persentase sebesar $40 \%$. Berdasarkan hasil pengolahan data bahwa sig. $0.927>0.05$, maka data daya kecepatan wasit dapat dikatakan berdistribusi normal. Kecepatan wasit berada pada kategori baik sekali dengan rata-rata 5 dan persentase sebesar $60 \%$. Berdasarkan hasil pengolahan data bahwa sig. $0.761>0.05$, maka data Kecepatan Wasit dapat dikatakan berdistribusi normal. Simpulan, daya tahan dan kecepatan wasit sepak bola CI Pengcap Kota Lubuklinggau berada pada kategori baik. Sedangkan daya tahan wasit sepak bola CII dalam kategori kurang, dan kecepatan wasit sepak bola CII pada kategori baik.
\end{abstract}

Kata Kunci: Daya Tahan, Kecepatan, Wasit

\begin{abstract}
The purpose of the study is to know the football referee physical condition of PSSI commitee in Lubuklinggau. The population of the study is fifteen football referees who live in Lubuklinggau and approved by PSSI committe of Lubuklinggau city. Total sampling is used because of limited population, therefore all the population (15 people) is taken as sample. Based on data analysis by using SPSS 12 version showed that sig. $0.918>0.05$, therefore the data of referee endurance is normal distribution. The referee speed is in good category which the mean score is 4 (40\%). Based on data analysis, sig. $0.927>0.05$. Therefore the data of referee speed is normal distribution. Referee speed is in very good category with the mean score 5 (60\%). Based on data analysis, referee speed is normal distrubution sig. $0.761>0.05$. Ins summary, football referee endurance and speed of CI committee lubuklinggau city is in good category. Meanwhile football referee endurance of CII is in low category and football referee speed of CII is in good category.
\end{abstract}

Keyword: Durability, Speed, Referee 


\section{PENDAHULUAN}

Olahraga merupakan kegiatan yang dibutuhkan oleh setiap orang, dengan berolahraga orang mendapatkan kesegaran jasmani, kesegaran pemikirannya dan berprestasi dalam pekerjaannya sehingga dapat meningkatkan produktifitas kerja. Di sisi lain olahraga juga dapat dijadikan ajang kompetisi untuk berpacu dalam penyampaian sebuah prestasi, sebagai wujud untuk mempertahankan prestasi baik secara individu, kelompok maupun negeri asal.

Undang-undang Nomor. 3 Tahun 2005 pasal 1 ayat 4 menyebutkan bahwa "olahraga adalah segala kegiatan yang sistematis untuk mendorong, membina serta mengembangkan potensi jasmani, rohani dan sosial. Lebih lengkap dalam pasal 4 menyebutkan tujuan keolahragaan Nasional yaitu "keolahragaan Nasional bertujuan memelihara dan meningkatkan kesehatan dan kebugaran prestasi, kualitas manusia, menanamkan nilai moral dan akhlak mulia, sportifitas, disiplin, mempererat dan membina persatuan dan kesatuan bangsa, memperkukuh pertahanan Nasional, serta mengangkat harkat, martabat dan kehormatan bangsa".

Sepakbola merupakan salah satu cabang olahraga yang sudah memasyarakat di Indonesia. Hal itu dapat kita lihat begitu banyaknya orang yang menggemarinya baik secara penonton maupun langsung sebagai pemain. Mulai dari perkotaan sampai perdesaan. Dari kalangan anak-anak sampai orang tua. Alasan merekapun beragam ada yang sekedar mengisi waktu luang, sekedar berolahraga sampai yang ingin mencapai prestasi tinggi. Hal ini ditandai dengan bertambahnya perkumpulan-perkumpulan atau klub-klub sepakbola baik sekolah sepakbola, Pusdiklat dan sebagainya. Bertambahnya perkumpulan sepakbola ini tidak saja terjadi di kota-kota akan tetapi pertambahannya juga terjadi di desadesa. Banyak sekali faktor-faktor yang mempengaruhi perkembangan sepakbola, diantaranya pelatih, sarana dan prasarana, sumber daya manusia dalam hal ini pemain atau atlet, satu hal dalam pertandingan sepakbola yang tidak dapat kita tinggalkan adalah yang memimpin suatu pertandingan yang lebih dikenal dengan Wasit. Untuk mengurangi tingkat kesalahan mengambil keputusan dalam pertandingan maka proses latihan diarahkan kepada pembinaan kondisi fisik, khususnya daya tahan dan kecepatan. Sebab faktor-faktor inilah yang sangat dominan dalam memimpin suatu pertandingan sepakbola sehingga menjadi sukses.

Berdasarkan uraian diatas dapat disimpulkan bahwa faktor kondisi fisik memegang peranan penting untuk pencapaian kepemimpinan dalam suatu pertandingan sepakbola. Tanpa adanya kondisi fisik, maka kemampuan fisik seorang Wasit yang diharapkan akan sulit dicapai karena tanpa kondisi fisik yang bagus maka seorang Wasit akan cepat mengalami kelelahan sehingga dalam mengambil keputusan tidak tepat lagi pada peraturan yang sesungguhnya.

Pada Wasit sepakbola Kota Lubuklinggau belum adanya pihak yang mendata tentang kemampuan kondisi fisik Wasit yang berdomosili di Kota Lubuklinggau, hal ini terlihat dari setiap digelarnya turnamen sepakbola sering terjadi kesalahan dalam mengambil keputusan sehingga protes dari pemain dalam lapangan dan hujatan dari para penonton di sebabkan oleh kurangnya kemampuan fisik Wasit tersebut.

Kurangnya kemampuan fisik Wasit sepakbola Pengcab PSSI Kota Lubuklinggau diduga karena rendahnya tingkat latihan kondisi fisik khususnya pada aspek daya tahan dan kecepatan yang dimiliki oleh Wasit sepakbola Kota 
Lubuklinggau. Hal tersebut terlihat pada saat memimpin suatu pertandingan, pada babak pertama Wasit dapat menguasai jalannya permainan dan dapat memperkecil tingkat kesalahan dalam mengambil keputusan. Namun pada babak kedua sudah tampak gejala menurunnya kondisi fisik Wasit sehingga tidak dapat lagi menempatkan jarak dengan bola yang mengakibatkan terjadinya kesalahan dalam mengambil keputusan.

Berdasarkan uraian di atas dapat disimpulkan bahwa faktor kondisi fisik memegang peranan penting untuk pencapaian kepemimpinan dalam suatu pertandingan sepakbola. Tanpa adanya kondisi fisik, maka kemampuan fisik seorang Wasit yang diharapkan akan sulit dicapai karena tanpa kondisi fisik yang bagus maka seorang Wasit akan cepat mengalami kelelahan sehingga dalam mengambil keputusan tidak tepat lagi pada peraturan yang sesungguhnya.

\section{KAJIAN TEORI}

\section{Hakikat Kondisi Fisik}

Untuk terwujudnya kesuksesan dalam memimpin pertandingan sepakbola, kondisi fisik Wasit sepakbola yang baik merupakan suatu hal yang sangat diperlukan, Jonath Krempel dalam Syafrudin (1999), mengatakan kondisi fisik itu dibedakan atas pengertian sempit dan luas. Dalam arti sempit kondisi fisik merupakan keadaan yang meliputi faktor kekuatan, kecepatan dan daya tahan. Sedangkan dalam arti luas adalah ketiga faktor kekuatan, kecepatan dan daya tahan ditambah dengan faktor kelenturan (fleksibility) dan koordinasi (coordination).

Menurut Sarumpaet (1986) mengatakan kondisi fisik adalah keadaan fisik seseorang pada saat tertentu untuk melakukan suatu pekerjaan yang dijadikan bebannya. Seseorang dapat dikatakan berada dalam kondisi fisik baik kalau ia mampu melakukan pekerjaan yang dibebankan kepadanya atau yang ingin dilakukannya tanpa kelelahan yang berlebihan. Sementara itu Prihastono (1999) berpendapat komponen kondisi fisik terdiri atas 2 bagian yaitu : pertama, kondisi fisik umum adalah kemampuan dasar untuk mengembangkan kemampuan tubuh yang terdiri dari: kekuatan, daya tahan, kecepatan, kelenturan dan kelincahan. Selanjutnya Frohner dalam Syafruddin (1996) bahwa latihan kondisi fisik umum berarti latihan-latihan yang beraneka ragam untuk mengembangkan kemampuan tubuh dan merupakan dasar untuk meningkatkan kemampuan kondisi fisik khusus. Sedangkan kemampuan kondisi fisik khusus merupakan kemampuan yang langsung dikaitkan dengan kebutuhan masing-masing cabang olahraga. Jonath dan Krempel dalam Syafrudin (1996) mengatakan bahwa bila kondisi dihubungkan dengan kemampuan prestasi dalam suatu cabang olahraga tertentu, maka kondisi disini disebut dengan kondisi fisik khusus.

Daya tahan secara umum menunjukan kemampuan menahan kelelahan

dari organ-organ tubuh manusia. Sedangkan aktifitas gerakan yang mempergunakan lebih besar dari jumlah otot-otot yang dibebani disebut dengan "daya tahan umum" dan jika daya tahan itu berlangsung di bawah pemakaian Oksigen $\left(\mathrm{O}_{2}\right)$ dinamakan "aerobik", dan sebaliknya jika aktifitas itu berlangsung tanpa menggunakan oksigen (O2) dinamakan dengan "anerobik", Fauzan Hos (1989).

Tujuan utama dari latihan daya tahan adalah meningkatkan kemampuan kerja jantung di samping meningkatkan kerja paru-paru dan sistem peredaran 
darah. Secara umum kemampuan daya tahan dibutuhkan dalam semua cabang olahraga yang membutuhkan gerak fisik. Selanjutnya (Darwis;1999) mengemukakan "daya tahan adalah kemampuan organisme seseorang untuk mengatasi kelelahan yang timbul setelah melakukan aktifitas tubuh berolahraga dalam waktu lama". Sedangkan yang dimaksud dengan endurance adalah kemampuan seseorang melaksanakan gerak dengan seluruh tubuhnya dalam waktu yang cukup lama dan dengan waktu sedang sampai cepat, tanpa mengalami rasa sakit dan kelelahan berat.

\section{Wasit Sepak Bola}

Wasit adalah seseorang yang memimpin dalam suatu pertandingan dan juga termasuk kedalam perangkat suatu pertandingan sepakbola, tanpa adanya Wasit yang memimpin dalam suatu pertandingan sepakbola maka pertandingan tersebut tidak akan bisa berlangsung. Sesuai dengan Pedoman Dasar PSSI menjadi seorang Wasit dapat di klasifikasikan sebagai berikut: C III Tingkat PENGCAB, C II Tingkat PENGDA, C I Tingkat Nasional dan FIFA Tingkat Internasional.

Untuk mencapai prsetasi ke tingkat Internasional Wasit FIFA, sertifikasi yang harus diikuti terlebih dahulu yaitu: mengikuti penataran Khursus Wasit C III Tingkat Pengcab yang diselenggarakan oleh masing-masing Pengcab. Selanjutnya mengikuti penataran khursus Wasit C II tingkat Pengda, yang diselenggarakan oleh Pengda di seluruh tanah air, dengan persyaratan antara lain: telah memiliki sertifikasi C III dan telah mengabdi minimal 2 tahun dengan usia di bawah 35 tahun, begitu juga dengan mengikuti penataran Wasit C I tingkat Nasional dengan persyaratan antara lain: telah memiliki sertifikasi Wasit C II dan mengabdi sekurangnya 2 tahun dengan usia tidak boleh lebih dari 35 tahun dengan ketentuan lulus mengikuti tes tertulis pemahaman peraturan permainan sepakbola dan tes kondisi fisik yang dikeluarkan oleh PSSI, seperti daya tahan dan kecepatan.

Dalam permainan sepakbola kategori usia pemain dapat dibedakan bermacam-macam, pembinaan pemain amatir PSSI mengenal klasifikasi pemain dalam kelompok usia, di bawah usia 14 tahun yang lama permainannya adalah 2 x 20 menit, di bawah usia 16 tahun lamanya permainan adalah 2 x 30 menit di bawah usia 19 tahun lama permainan adalah 2 x 40 menit, dan di bawah usia 23 tahun lama permainan adalah 2 x 45 menit (Peraturan permainan sepakbola PSSI).

Adapun beberapa tugas dan kekuasaan seorang Wasit adalah memimpin pertandingan bekerjasama dengan asisten Wasit, menegakkan peraturan permainan, memastikan bahwa setiap bola yang dipergunakan dalam bertanding telah memenuhi persyaratan yang ditentukan, memastikan perlengkapan pemain telah memenuhi persyaratan yang telah ditentukan, bertindak sebagai pencatat waktu dan mencatat hasil pertandingan, membuat keputusan untuk menghentikan, menunda atau mengakhiri pertandingan, menghentikan permainan apabila seoarng pemain mengalami cedera, memberikan hukuman atau tindakan disiplin terhadap pelanggaran yang dilakukan oleh pemain berupa kartu kuning dan kartu merah, memberikan tindakan terhadap official tim yang bertindak dengan cara-cara yang tidak bertanggung jawab, melarang orang yang tidak berkepentingan masuk ke dalam lapangan permainan, memulai kembali pertandingan setelah dihentikan, membuat laporan pertandingan atas kejadian yang dialami pada saat memimpin pertandingan dan menyerahkannya kepada pihak yang berwenang. 
Adapun keputusan Wasit mengenai fakta-fakta yang berkaitan dengan permainan adalah mutlak (final). Begitu juga dengan tugas asisten Wasit antara lain: memberikan isyarat apabila keseluruhan bagian bola telah keluar dari lapangan permainan, mengisyaratkan pihak mana yang berhak untuk suatu tendangan sudut, tendangan gawang atau lemparan ke dalam, mengisyaratkan bahwa pemain dapat dihukum karena berada dalam posisi ofsaid, memberikan isyarat apabila ada pergantian pemain, memberikan isyarat apabila terjadi pelanggaran atau insiden yang tidak terlihat ketika itu asisten Wasit berada lebih dekat dari kejadian dari pada Wasit. Melihat dari tugas dan kekuasaan Wasit dan asisten wasit yang telah diuraikan di atas, tidak mungkin rasanya seorang Wasit dan asisten wasit akan memimpin pertandingan secara adil dan bijaksana tanpa diiringi oleh kondisi fisik yang bagus sehingga dapat memperkecil kesalahan dalam pertandingan

\section{METODE PENELITIAN}

Jenis penelitian ini adalah penelitian bersifat deskriptif dimana peneliti hanya melihat bagaimana kemampuan kondisi fisik wasit sepakbola kota Lubuklinggau. Pelaksanaan metode-metode deskriptif tidak hanya terbatas sampai pada pengumpulan data dan penyusunan data, tetapi meliputi analisis dan interprestasi tentang arti data itu.

Populasi penelitian ini adalah Wasit-wasit yang terdaftar sebagai anggota wasit Pengcab PSSI Kota Lubuklinggau yang terdiri dari wasit C I dan C II yang berdomisili di Lubuklinggau. Sedangkan untuk wasit C III tidak masuk ke dalam populasi karena di kota Lubuklinggau belum ada wasit yang tergolong dalam $\mathrm{C}$ III. Berpedoman kepada populasi maka sampel yang diambil menggunakan teknik total sampling. Karena jumlah populasi yang relatif sedikit, maka semua populasi dijadikan sampel yaitu sebanyak 15 orang dengan kriteria wasit CI dan CII yang berdomisili di kota Lubuklinggau.

Jenis data penelitian yang diambil dalam suatu penelitian yaitu : data primer (data yang diambil langsung melalui tes kondisi fisik wasit sepakbola Kota Lubuklinggau) dan sekunder (data yang diambil dari pengurus Pengcab PSSI Kota Lubuklinggau). Data yang diperoleh dalam penelitian ini diambil langsung dari Wasit yang berdomisili di Kota Lubuklinggau. Teknik pengumpulan data dalam penelitian ini adalah Tes Kecepatan lari 6 x 40 meter dan tes Daya Tahan lari 20 x 150 meter (kedua tes di atas berdasarkan petunjuk Tes Kesehatan/Kebugaran Wasit FIFA/AFC/PSSI 2008).

Instrument dalam penelitian ini yakni peserta berdiri dibelakang garis star, dengan sikap star berdiri. Pada saat bendera diangkat oleh starter peserta berusaha lari secepat mungkin mencapai garis finis, kemudian berjalan kembali ke garis star diikuti dengan pemulihan 1,5 menit/ 90 detik. Tiap Peserta melakukan 6 kali pengulangan dengan jarak tempuh 40 meter. Sedangkan prosedur penelitian dengan mendapatkan izin penelitian dari Ketua Pengcab PSSI Kota Lubuklinggau, melakukan tera alat ukur dari Dinas Perindustrian dan Perdagangan UPTD Balai Tentang Pemeriksaan dan mendapatkan rekomendasi untuk melakukan penelitian terhadap Wasit Sepakbola Pengcab Kota Lubuklinggau serta menyiapkan tenaga pembantu

Setelah hasil data di lapangan dikumpulkan selanjutnya dilakukan pengelolaan data berdasarkan data yang terkumpul dan telah memenuhi syarat 
untuk dianalisa, teknik analisa data dilakukan dengan menggunakan deskriptif yang menggunakan tabulasi frekruensi dan rata-rata dan dibantu dengan program komputer SPSS V.12 dengan rumus sebagai berikut:

$$
\mathrm{P}=\frac{\mathrm{F}}{\mathrm{N}} \times 100 \%
$$

Keterangan :

$$
\begin{aligned}
& \mathrm{P}=\text { Persentase } \\
& \mathrm{F}=\text { Frekruensi } \\
& \mathrm{N}=\text { Jumlah Sampel }
\end{aligned}
$$

\section{HASIL PENELITIAN}

\section{Uji Normalitas Wasit CII Tingkat Pengda Daya Tahan Lari 20 x 150 Meter}

Analisis uji normalitas dalam penelitian bertujuan untuk menguji asumsi bahwa distribusi sampel dari data sampel mendekati normalitas populasi. Pengujian normalitas penyebaran skor data dengan menggunakan Uji ShapiroWilk. Taraf signifikansi yang digunakan sebagai dasar menolak atau menerima keputusan normal / tidaknya suatu distribusi data adalah $\mathrm{Ha}$ : data populasi berdistribusi normal, Ho : data populasi tidak berdistribusi normal

Dasar pengambilan keputusan, jika skor Statistik > Signifikan Alpha $(0,05)$ berarti Ha diterima, jika skor Statistik < Signifikan Alpha $(0,05)$ berarti Ha ditolak. Hasil perhitungan uji normalitas yakni sebagai berikut:

Tabel 1

Uji normalitas data Daya Tahan Wasit dengan Uji Shapiro Wilk.

\begin{tabular}{lrrrrrrr}
\hline & \multicolumn{3}{c}{ Kolmogorov-Smirnov(a) } & \multicolumn{4}{c}{ Shapiro-Wilk } \\
\cline { 2 - 8 } Daya tahan wasit CII & \multicolumn{2}{c}{ Statistic } & Df & Sig. & Statistic & Df & Sig. \\
\cline { 2 - 8 } & & .292 & 10 & .002 & .808 & 10 & .006 \\
\hline
\end{tabular}

a. Lilliefors Significance Correction

Dari tabel 1, dapat dilihat skor Signifikansi untuk kondisi fisik Wasit CII Pengcab Kota Lubuklinggau dilihat dari segi daya tahan sebesar 0.808 . Berdasarkan landasan pengambilan keputusan di atas, Ha diterima. Dengan demikian dapat dinyatakan bahwa data dari kondisi fisik Wasit CII sepakbola Pengcab Kota Lubuklinggau dilihat dari segi daya tahan dalam penelitian ini sebenarnya membentuk distribusi normal.

\section{Uji Normalitas Wasit CI Tingkat Nasional Daya Tahan Lari 20 x 150 Meter.}

Analisis uji normalitas dalam penelitian bertujuan untuk menguji asumsi bahwa distribusi sampel dari data sampel mendekati normalitas populasi. Pengujian normalitas penyebaran skor data dengan menggunakan Uji ShapiroWilk. Taraf signifikansi yang digunakan sebagai dasar menolak atau menerima keputusan normal / tidaknya suatu distribusi data adalah $\mathrm{Ha}$ : data populasi berdistribusi normal, Ho : data populasi tidak berdistribusi normal. Dasar pengambilan keputusan, jika skor Statistik > Signifikan Alpha $(0,05)$ berarti Ha diterima, jika skor Statistik < Signifikan Alpha $(0,05)$ berarti Ha ditolak. Hasil perhitungan uji normalitas dapat dilihat pada lampiran dan seperti di bawah ini: 
Tabel 2

Uji normalitas data Daya tahan wasit CI dengan Uji Shapiro Wilk.

\begin{tabular}{lrrrrrrr}
\hline & \multicolumn{3}{c}{ Kolmogorov-Smirnov(a) } & \multicolumn{3}{c}{ Shapiro-Wilk } \\
\cline { 2 - 8 } Daya tahan wasit CI & \multicolumn{2}{c}{ Statistic } & Df & Sig. & Statistic & Df & Sig. \\
\cline { 2 - 8 } & & .183 & 5 & .200 & .918 & 5 & .341 \\
\hline
\end{tabular}

a. Lilliefors Significance Correction

Dari tabel 2, dapat dilihat skor Signifikansi untuk kondisi fisik Wasit CI Pengcab Kota Lubuklinggau dilihat dari segi daya tahan sebesar 0.918. Berdasarkan landasan pengambilan keputusan di atas, Ha diterima. Dengan demikian dapat dinyatakan bahwa data dari kondisi fisik Wasit CI sepakbola Pengcab Kota Lubuklinggau dilihat dari segi daya tahan dalam penelitian ini sebenarnya membentuk distribusi normal.

\section{Uji Normalitas Wasit CII Tingkat Pengcap Wasit CII dari Segi Kecepatan Lari 6 x 40 Meter.}

Analisis uji normalitas dalam penelitian bertujuan untuk menguji asumsi bahwa distribusi sampel dari data sampel mendekati normalitas populasi. Pengujian normalitas penyebaran skor data dengan menggunakan Uji ShapiroWilk. Taraf signifikansi yang digunakan sebagai dasar menolak atau menerima keputusan normal / tidaknya suatu distribusi data adalah $\mathrm{Ha}$ : data populasi berdistribusi normal, Ho : data populasi tidak berdistribusi normal. Dasar pengambilan keputusan, jika skor Statistik > Signifikan Alpha $(0,05)$ berarti Ha diterima, jika skor Statistik < Signifikan Alpha $(0,05)$ berarti Ha ditolak. Hasil perhitungan uji normalitas dapat dilihat pada lampiran dan seperti di bawah ini:

Tabel 3

Uji normalitas data kecepatan wasit CII dengan Uji Shapiro Wilk

\begin{tabular}{lrrrrrrr}
\hline & \multicolumn{3}{c}{ Kolmogorov-Smirnov(a) } & \multicolumn{3}{c}{ Shapiro-Wilk } \\
\cline { 2 - 7 } Daya tahan wasit CII & \multicolumn{2}{c}{ Statistic } & Df & Sig. & Statistic & Df & Sig. \\
\cline { 2 - 7 } & & .177 & 10 & .200 & .927 & 10 & .274 \\
\hline
\end{tabular}

a. Lilliefors Significance Correction

Dari tabel 3, dapat dilihat skor Signifikansi untuk kondisi fisik Wasit CII Pengcab Kota Lubuklinggau dilihat dari segi daya tahan sebesar 0.927. Berdasarkan landasan pengambilan keputusan di atas, Ha diterima. Dengan demikian dapat dinyatakan bahwa data dari kondisi fisik Wasit CII sepakbola Pengcab Kota Lubuklinggau dilihat dari segi kecepatan dalam penelitian ini sebenarnya membentuk distribusi normal. 


\section{Uji Normalitas Wasit CI Tingkat Pengcap Wasit CI dari Segi Kecepatan Lari 6 x 40 Meter.}

Analisis uji normalitas dalam penelitian bertujuan untuk menguji asumsi bahwa distribusi sampel dari data sampel mendekati normalitas populasi. Pengujian normalitas penyebaran skor data dengan menggunakan Uji ShapiroWilk. Taraf signifikansi yang digunakan sebagai dasar menolak atau menerima keputusan normal / tidaknya suatu distribusi data adalah $\mathrm{Ha}$ : data populasi berdistribusi normal, Ho : data populasi tidak berdistribusi normal. Dasar pengambilan keputusan, jika skor Statistik > Signifikan Alpha $(0,05)$ berarti Ha diterima, jika skor Statistik < Signifikan Alpha $(0,05)$ berarti Ha ditolak. Hasil perhitungan uji normalitas dapat dilihat pada lampiran dan seperti di bawah ini:

Tabel 4

Uji normalitas data kecepatan wasit CI dengan Uji Shapiro Wilk

\begin{tabular}{|c|c|c|c|c|c|c|}
\hline \multirow{3}{*}{ Daya tahan wasit CI } & \multicolumn{3}{|c|}{ Kolmogorov-Smirnov(a) } & \multicolumn{3}{|c|}{ Shapiro-Wilk } \\
\hline & Statistic & Df & Sig. & Statistic & Df & Sig. \\
\hline & .310 & 10 & .007 & .761 & 10 & .005 \\
\hline
\end{tabular}

a. Lilliefors Significance Correction

Dari tabel 4, dapat dilihat skor Signifikansi untuk kondisi fisik Wasit CI Pengcab Kota Lubuklinggau dilihat dari segi daya tahan sebesar 0.761. Berdasarkan landasan pengambilan keputusan di atas, Ha diterima. Dengan demikian dapat dinyatakan bahwa data dari kondisi fisik Wasit CI sepakbola Pengcab Kota Lubuklinggau dilihat dari segi kecepatan dalam penelitian ini sebenarnya membentuk distribusi normal.

\section{Kondisi Fisik wasit sepakbola Pengcab PSSI Kota Lubuklinggau dilihat dari segi daya tahan lari 20 x 150 Meter}

Data kondisi fisik wasit sepakbola Pengcab PSSI Kota Lubuklinggau yang diperoleh dari studi langsung kepada 15 orang wasit sepakbola Pengcab PSSI Kota Lubuklinggau, dalam pembahasan ini akan di bagi dalam tingkatan wasit menurut kualifikasi wasit yang terdiri dari CII PENGDA dan CI NASIONAL. Dalam penilaian hasil pengukuran yang dilakukan terhadap 10 orang wasit CII tingkat PENGDA diperoleh skor tertinggi 18, skor terendah 11, mean sebesar 12,57, median sebesar 12, modus sebesar 12, Dan simpangan baku sebesar 2,02. Sedangkan untuk kondisi fisik wasit CII yang dijadikan sampel di dalam penelitian ini, terbanyak berada pada skor nilai 10.5-12.4.

Selanjutnya hasil pengukuran yang dilakukan terhadap 10 orang wasit CI tingkat Nasional diperoleh skor tertinggi 20, skor terendah 11, mean sebesar 15.1, median sebesar 14.5, modus sebesar 16 dan simpangan baku sebesar 3.03. Sedangkan kondisi fisik wasit CI yang dijadikan sampel di dalam penelitian ini, terbanyak berada pada skor nilai 14.5-16.4 dan 12.5-14. 


\section{Kondisi Fisik wasit sepakbola Pengcab PSSI Kota Lubuklinggau dilihat dari segi kecepatan lari 6 x 40 meter}

Data kondisi fisik wasit sepakbola Pengcab PSSI Kota Lubuklinggau yang diperoleh dari studi langsung kepada 15 orang wasit sepakbola Pengcab PSSI Kota Lubuklinggau, dalam pembahasan ini akan di bagi dalam tingkatan wasit menurut kualifikasi wasit yang terdiri dari CII PENGDA dan CI NASIONAL. Dalam penilaian hasil pengukuran yang dilakukan terhadap 10 orang wasit CII tingkat Pengda diperoleh skor tertinggi 6, skor terendah 1, mean sebesar 4,14, median sebesar 4, modus sebesar 4, Dan simpangan baku sebesar 1,51. Sedangkan kondisi fisik wasit CII yang dijadikan sampel di dalam penelitian ini, terbanyak berada pada skor nilai 3.5 - 4.4. Dapat dilihat bahwa wasit C II Pengda dari segi daya tahan lari $20 \times 150$ Meter dengan waktu 3 orang (30\%) berada pada kategori baik sekali, 4 orang (40\%) barada pada ketegori baik, 2 orang (20\%) barada pada ketegori cukup dan 1 orang $(10 \%)$ pada kategori kurang. Jadi berdasarkan klasifikasi di atas dapat dinyatakan bahwa wasit C II Pengda dari segi daya tahan lari $20 \times 150$ Meter berada pada ketegori baik sekali dengan rata-rata 4.1 dan persentase $40 \%$.

Selanjutnya dalam penilaian hasil pengukuran yang dilakukan terhadap 5 orang wasit CI tingkat Nasional diperoleh skor tertinggi 6, skor terendah 1, mean sebesar 4,6, median sebesar 5, modus sebesar 5, Dan simpangan baku sebesar 1,42. Sedangkan kondisi fisik wasit CI yang dijadikan sampel di dalam penelitian ini, terbanyak berada pada skor nilai $4.5-5.4$. bahwa 3 orang $(60 \%)$ wasit C I Nasional dari segi daya tahan lari 20 x 150 Meter dengan waktu 30 detik recovery 50 detik berada pada ketegori baik sekali, 1 orang $(20 \%)$ barada pada kategori baik dan 1 orang (20\%) barada pada ketegori cukup. Jadi berdasarkan klasifikasi di atas dapat dinyatakan bahwa wasit C I Nasional dari segi daya tahan lari $20 \mathrm{x}$ 150 Meter berada pada ketegori baik sekali dengan rata-rata 4.5 dan persentase $60 \%$.

\section{PEMBAHASAN}

\section{Kondisi fisik wasit sepakbola Pengcap PSSI Kota Lubuklinggau dilihat dari Segi Daya Tahan}

Daya tahan merupakan elemen kondisi fisik yang terpenting. Oleh karena itu, basis dari elemen-elemen kondisi fisik yang lain. Weineck dalam Safrudin (1999) mengartikan daya tahan sebagai kemampuan tubuh dalam mengatasi kelelahan fisik dan psikis (mental). Tujuan utama dari latihan daya tahan adalah meningkatkan kemampuan kerja jantung disamping meningkatkan kerja paru-paru dan sistem peredaran darah. Secara umum kemampuan daya tahan dibutuhkan dalam semua cabang olahraga yang membutuhkan gerak fisik.

Selanjutnya Arsil (1989) menjelaskan bahwa daya tahan dalam permainan sepakbola merupakan kesanggupan tubuh untuk melakukan aktivitas selama berlangsungnya permainan. Menjadi seorang wasit sepakbola, daya tahan sangat dibutuhkan, hal ini dikarenakan seorang wasit sepakbola hendaklah aktif dalam lapangan selama permainan berlangsung.

Berdasarkan uraian dari analisis data di atas dapat dinyatakan bahwa daya tahan wasit CII Tingkat Pengda dibawah naungan Pengcap Lubuklinggau berada pada kategori kurang dengan rata-rata 10 , ini artinya bahwa wasit CII hanya mampu melakukan 5 kali pengulangan dalam melakukan lari satu lintasan 
lapangan. Selanjutnya wasit CI Nasional berada pada kategori baik dengan ratarata 15 , ini artinya bahwa wasit CI hanya mampu melakukan 5 kali pengulangan dalam melakukan lari satu lintasan lapangan. Dari gambaran di atas dapat disimpulkan kemampuan kondisi fisik wasit sepakbola Pengcap PSSI Kota Lubuklinggau berdasarkan tes daya tahan berada pada taraf baik.

Sebagai upaya dari insan perwasitan kota Lubuklinggau, untuk dapat menjadi perhatian pada masa yang akan datang, hendaklah kiranya dapat meningkatkan kebugaran tubuh para wasit dalam hal ini daya tahan. Dengan kondisi fisik yang bagus maka wasit akan bisa meminimalisir kesalahan-kesalahan yang terjadi dilapangan.

\section{Kondisi fisik wasit sepakbola Pengcap PSSI Kota Lubuklinggau dilihat dari segi Kecepatan.}

Jonath dan krempel dalam Syafruddin (1999) mengatakan "kecepatan dibatasi oleh faktor-faktor seperti ; Kekuatan, Kecepatan dan koordinasi. Pada seorang Wasit sepakbola yang memiliki kecepatan yang baik akan mampu berada saat terjadinya pelanggaran atau kejadian-kejadian dalam pertandingan sepakbola, tidak hanya mengambilkan keputusan yang adil pada pasal 12 peraturan umum pertandingan sepakbola.

Dalam kontek ini wasit mencakup dari semua komponen yang membatasi faktor-faktor yang kecepatan. Tidak hanya seorang wasit cepat, tetapi juga harus ada keseimbangan antara komponen-komponen yang tercakup didalamnya. Dari hasil pengukuran diatas didapat bahwa wasit CII dilihat dari segi kecepatan berada pada ketegori baik dengan rata-rata 4 , dan wasit CI dilihat dari segi kecepatan berada pada ketegori baik sekali dengan rata-rata 5 .

\section{SIMPULAN}

Berdasarkan deskripsi data dan pembahasan di atas, maka dapat di tarik kesimpulan sebagai berikut: daya tahan dan kecepatan wasit sepak bola CI Pengcap Kota Lubuklinggau berada pada kategori baik. Sedangkan daya tahan wasit sepak bola CII dalam kategori kurang, dan kecepatan wasit sepak bola CII pada kategori baik.

\section{DAFTAR PUSTAKA}

Arsil (1989) Pentingnya Latihan Kondisi Fisik Untuk Meningkatkan Prestasi Pemain Sepakbola Makalah. Lubuklinggau: FPOK IKIP

Darwis, R. (1999). Sepakbola. Universitas Negeri Padang

FIFA, (2005) Peraturan Permainan (Laws of the game), Jakarta: Bidang Sumber Daya PSSI

Hos, F. (1989) Teori Gerak. Lubuklinggau ; FPOK. IKIP

Prihastono, A. (1999). Pembinaan Kondisi Fisik Karate, Solo; CV Aneka

PSSI, (2003). Peraturan Umum Pertandingan; Jakarta

Sarumpeat, A. (1986). Dasar-dasar Pembinaan Gulat. Jakarta: Gramedia

Syafruddin, (1999). Dasar-dasar Kepelatihan Olahraga. Lubuklinggau: FIKUNP 